\title{
Between mercantilism and market: privileges for invention in early modern Europe
}

\author{
CARLO MARCO BELFANTI* \\ University of Brescia, Italy
}

\begin{abstract}
This paper aims at offering a reconstruction of the salient features of the most important formal institution introduced by European states in the Early Modern Period with the aim of recognizing and protecting the intellectual property of the inventors. Such institutions went under different names 'Privilegio' in Venice, 'Patent' in England, 'Privilège' in France, 'Cedula de privilegio de invençion' in Spain - and, in general, took the form of the concession of a special prerogative to the inventor by the sovereign or the republic, by virtue of which he could exploit, in economic terms, his own invention through holding a monopoly. The article starts with the origins of the privileges for invention, of which the first examples are to be found in the Middle Ages, but whose official 'genesis' is commonly identified with the Venetian law of 1474 . The fundamental characteristics of the Venetian system, which was later imitated by other European states, are analysed. In the following section, the adoption of this model by those other states - Spain, France, England, and the Netherlands - is illustrated. In fact, the majority of these would make legislation on intellectual property an instrument of mercantilist policy, under the same conditions as prevailed in Venice. Further, we will examine some of the opportunities that the diffusion of these measures offered to those involved and the way in which they as craftsmen, merchants, and speculators - took advantage of the business of privileges. Finally, before concluding, some thoughts on the changes made in the policy of privileges given the transformations that took place in the course of the eighteenth century, in order to understand the 'adaptive' capacity of these institutions.
\end{abstract}

\section{Introduction}

This paper aims at offering a reconstruction of the salient features of the most important formal institution introduced by European states in the Early Modern Period with the aim of recognizing and protecting the intellectual property of the

The author thanks Liliane Hilaire-Pérez, Ian Inkster, Christine MacLeod, Jacques Mairesse and anonymous referees for their comments and suggestions.

*Correspondence to: Carlo Marco Belfanti, Dipartimento di Studi Sociali, Università degli Studi, Via S. Faustino 74b, 25122 Brescia, Italy. Email: belfanti@eco.unibs.it 
inventors. ${ }^{1}$ Such institutions went under different names - 'Privilegio' in Venice, 'Patent' in England, 'Privilège' in France, 'Cedula de privilegio de invençion' in Spain - and, in general, took the form of the concession of a special prerogative to the inventor by the sovereign or the republic, by virtue of which he could exploit, in economic terms, his own invention through holding a monopoly. It is, however, opportune to remember that the concession of privileges was not regarded only as a measure exclusively reserved for inventors, but, instead, was widely used by the political powers - republican or monarchic as the case may be - to reward or to gain the fidelity of single individuals or organizations by distributing benefits, exemptions, and special prerogatives: that is privileges.

If the privilege was the formal institution through which the inventor could obtain recognition of his rights from the state, it is nonetheless mandatory to underline from the start that there were also other means, at times complementary, but most frequently alternative to the concession of the privilege, which allowed a person to obtain economic advantages from an invention. We will deal with these again further on in our discussion. In many cases, it was the guild system that constituted the organizational framework and the institutional context within which the craftsman could find adequate recognition for the fruit of his ingenuity. In other countries or situations, it was the numerous scientific societies which arose throughout Europe in the seventeenth century and which had been founded with the scope of encouraging scientific and technical progress that arbitrated the inventive activity, acknowledging its validity through public testimonials and money prizes. And, last but not least, there was secrecy, which in determinate conditions, was the most effective way of protecting an invention from imitators and of enjoying the economic advantages deriving from it.

These are only the most-well known of the opportunities that could offer some form of protection and recognition of intellectual property and which often were in competition with the privilege. Analysing such opportunities does not come under the objectives of this paper, but I believe it to be important to underline that we are dealing with two strictly related fields. In other words, the institutional evolution, the mode of applying for and granting privileges, and, in the latter instance, the effectiveness of the privilege itself for inventions can also be explained in relation to the existence or otherwise of alternative solutions.

The study proposed here is based on the existing literature, which is not particularly extensive. Only recently, in fact, have important, in-depth studies appeared which renew and enrich a traditional scholarship of a prevalently historical-juridical slant. In the analysis which follows, I have therefore chosen to take into account the best documented cases, which, nonetheless, represent

1 I use here the term 'inventor' only for simplicity: in the Early Modern Period, the actors of the inventive activity were mainly craftsmen and technicians. 
a significant sample of the European experience regarding institutions for the safeguarding of intellectual property.

The article starts with the origins of the privileges for invention, of which the first examples are to be found in the Middle Ages, but whose official 'genesis' is commonly identified with the Venetian law of 1474. The fundamental characteristics of the Venetian system, which was later imitated by other European states, are analysed. In the following section the adoption of this model by those other states - Spain, France, England, and the Netherlands - is illustrated. In fact, the majority of these would make legislation on intellectual property an instrument of mercantilist policy, under the same conditions as prevailed in Venice. Further, we will examine some of the opportunities that the diffusion of these measures offered to those involved and the way in which they as craftsmen, merchants, and speculators - took advantage of the business of privileges. Finally, before concluding, some thoughts on the changes made in the policy of privileges given the transformations that took place in the course of the eighteenth century, in order to comprehend the 'adaptive' capacity of these institutions (David, 1993: 43).

\section{The origins}

Effective focusing of the concept of intellectual property dates back to the Late Middle Ages and in particular to the thirteenth and fourteenth centuries when the urban civilization of Northern Italy emerged and established itself. The Italian cities of that period, centres of prosperous craft activity and of advanced mercantile culture, were the institutional testing ground in which the first nucleus of the idea of intellectual property was moulded. More precisely, it was within the guild organizations that this concept took shape. In the organizational set-up of the mediaeval city-state the guilds were assigned the function of the codifying in a more or less formal fashion - of the safeguarding and of the transmission of craft knowledge from generation to generation. It was in this context that 'proprietary attitudes to craft knowledge' (Long, 2001: 89) emerged, where knowledge was held to be an intangible form of property, clearly distinct both from the object produced and from the manual labour needed to realize it. The example of the Venetian guild of glassmakers, at the top of the tree in the hierarchical levels of craft specialization, as analysed by Pamela Long, clearly illustrates how, between the thirteenth and the fourteenth centuries, this group of craftsmen acquired the awareness of being able to manage their own skills as an intangible property (Long, 1991: 870-875). ${ }^{2}$

In the Italian cities of the Late Middle Ages, there was a close relationship between the political power and the guild organization. It is therefore not surprising that the formulation of the concept of intellectual property, elaborated 
within the world of the craft guilds with the aim of enhancing the value of the craft knowledge handed down in the workshops, was also accepted by the city government who made it its own. The rulers, aware of the fundamental role played by skilled artisans in the economic prosperity of the city, adopted an instrument of economic policy aimed at attracting craftsmen from outside the state, who were able to enrich that state by setting up new manufacture, thanks to the importation of new production techniques (Long, 2001: 92-93). The importance of this strategy is emphasized by Giovanni Botero, author of important writings on political science among which is the treatise on the 'Causes of the greatness of the cities', published at the end of the sixteenth century, which proclaimed: 'The prince who wishes to render his city populous should therefore introduce every sort of industry and artifice, which will bring master craftsmen from other places. (He should) give them housing and comfort and take great ingenuity into account and esteem invention and those works which savour of the singular or the rare, rewarding perfection and excellence' (Botero, 1948: 249).

Princes, Republics, and City Councils offered prizes, incentives, and tax relief to craftsmen who were willing to move to their cities, in recognition of the value of the craft knowledge of which they were the repositories. The act of conceding such benefits took on the institutional form of privilege, by virtue of which the beneficiary enjoyed a series of special prerogatives.

The Republic of Venice had a pioneering role in the history of privileges for inventions. The oldest documentary evidence relative to the concession of privileges comes from between the end of the thirteenth century and the first decade of the fourteenth, a period in which measures were adopted to favour the introduction of inventions for the construction of a new type of mill (Mandich, 1958). In the fifteenth century, the recourse to privileges to obtain adequate recognition for an invention became more frequent and was, moreover, introduced outwith the confines of the Venetian state. For example, there is a privilege dating from 1421 granted to Filippo Brunelleschi by the Comune of Florence for the invention of a boat for river transport (Long, 1991: 878-879; Long, 2001: 96-100). But Venice was the first to approve a specific law regarding privileges for inventions. The law, approved by the Senate in 1474 , codified the procedures that had hitherto been applied sporadically throughout the century. It established that those who had thought of or realized innovative processes or products could, by having their invention registered, obtain a ten year monopoly within which to exploit that invention, with the faculty of being able to ask for eventual infringements to be prosecuted by the law of the state (Mandich, 1936: 517-520). The Senate in Venice thus formally recognized intellectual property and guaranteed the protection of the rights of the inventor against plagiarism.

The principal political and economic objective of the 1474 law - as for all the measures taken in other European states on the Venetian model - was that 
of attracting specialized craftsmen and technicians from other countries: an aim explicitly declared in the preface to the law itself. The text of the law, in fact, begins by recognizing the fundamental value of the contribution that foreigners could make to increasing the state's patrimony of technical knowledge (Mandich, 1936: 518). As a consequence, the need for a process or a product to have innovative character, a requisite that offered the chance of obtaining a privilege, was limited only to the territory of the Venetian Republic itself. That is, it had to be new to Venice, not new in an absolute sense. In this perspective, the Venetian government was not even interested in ascertaining whether the applicants were in fact the real originators of the invention or whether they were dealing with a case of theft or plagiarism.

While the law foresaw that the state should safeguard the rights relative to inventions whose effective utility had been proved, it was not unusual for this proof to be partly deficient or wholly lacking. At times descriptions, drawings, or models from which it was not easy to judge the efficacy of the invention accompanied the applications. As can be readily understood, the judgement of merit that the Venetian magistrates were called upon to make on the question of the applications for privileges did not have to be particularly profound (Mandich, 1936: 522-525). The functioning of the institution - otherwise of dubious validity - was ensured by the clause that obliged the privilege holder to put the invention into practice within a set time, on pain of losing every right over it. This clause, already present in the measures of the fifteenth century, became increasingly frequent as time went on (Mandich, 1936: 525-529; Berveglieri, 1995: 27-28). We can deduce that the policy of privileges adopted by the Venetian government was that of not committing itself too far to the onerous and fruitless process of a deep examination of the technical merits of the inventions offered, but rather that of limiting itself to examining the applications in the light of the political and economic needs of the Republic, and then leaving it up to the market, thanks to the clause regarding the effective putting into practice of the invention, to make a final judgement on its worth.

We need to go back to the second half of the fifteenth century - to be precise to 1486 - to find the first Venetian granting of a privilege to protect the rights of authors, printers, and editors. This first measure - the ancestor of our modern copyright - was followed by other of a similar tone, but we must point out that, despite significant analogies with the patents for invention, we are still dealing with institutions that were totally distinct, both as far as regards their administrative bodies and as regards legislation (Mandich, 1936: 532-537). It is licit therefore to believe that the definition of the concept of intellectual property, that was matured within the craft world and codified by the Venetian law of 1474, was introduced into the emerging sector of editorial activity at a later date (Long, 2001: 11-12) . $^{3}$. 


\section{Diffusion of a pattern}

One of the reasons which explain the diffusion of the Venetian model for the protection of the rights of inventors lies probably in the fact that it responded in a relatively simple manner to a need that was widely perceived on the European continent, where political power was becoming increasingly aware of the importance of technical know-how for economic growth. Moreover, we may add that the institutional form of the privilege could be included within the institutional framework of the absolute monarchies without causing any trauma: it reinforced its character of gracious concession, of patronage, of 'octroi'.

The first case of a 'Cedula de privilegio de invençion' granted by the Crown of Castille was that obtained in 1478 by Pedro Azlor for a new type of mill. The concession allowed the inventor a 20 -year right to enjoy the economic advantages deriving from exclusive exploitation of the new machine and prescribed heavy sanctions against any who copied it (Garcia Tapia, 1998). We are not given to know with any certainty whether the Venetian law of 1474 was known at the Castilian court, but there is no doubt that the privilege granted to Azlor was inspired by similar concepts. In the following century, that in which the greatest number of privileges granted in the Early Modern Period is recorded, the procedure was consolidated; the duration of the rights of the privilege holder could vary from ten to 40 years and its application could be limited to one place or extended over all the Empire. That which would appear to partially distinguish the Castilian experience from the Venetian model was the preliminary examination; the crown could in fact bind the concession of the privilege to the judgement of the experts charged with examining the validity of the invention proposed (Garcia Tapia, 1990 and 1998; Saiz Gonzàlez, 1999).

Some social scientists working in the field of the institutions and organizations maintain that the diffusion of institutional forms is often realized through ties created by sharing cultural values and social behaviour and by the action of networking (Brown, 1981; Strang and Meyer, 1993). Such an interpretation can be applied to the Italian craftsmen who emigrated abroad in search of their fortunes over the course of the sixteenth century, who may have spread the 'culture' of the privilege for invention (Long, 1991: 879-881). For example, a Bolognese glassworker, in whose petition the influence of the Venetian laws is evident, obtained one of the first privileges granted in France (Mandich, 1936: 536). In fact, from the third and fourth decades of the sixteenth century, the French crown had encouraged the immigration of Italian craftsmen with the aim of developing national, internal manufacture and of halting the importation of luxury goods from Italy (Heller, 2000: 251-252). The flow of specialized craftsmen, on the other hand, pushed the monarchy into elaborating the definition of a legal framework into which to fit the new arrivals (Hilaire-Pérez, 2000b: 42). 
From the beginning of the seventeenth century the management of the mercantilist strategies of the crown was placed into the hands of a state commission, as Barthélémy Laffemas had fought for it to be. The tasks of the commission also included the enrichment of the patrimony of technical knowhow by attracting craftsmen from abroad (Heller, 2000: 254; Hilaire-Pérez, 2000b: 48-49). In sixteenth-century France, the institution of the privilege for invention was adopted as an instrument for the mercantilist policy pursued by the monarchy; this is probably the only element of strong similarity with the Venetian model, from which the French experience was distinguished by other aspects. A first element of distinction was given by the existence of two different political powers, not infrequently contra posed one to each other, which had the faculty of intervening in the process of the concession of the privilege: these were the monarchy on one hand and the parliament on the other. A second, not less important peculiarity of the French model was represented by the severity with which the applications for privileges were examined. The protection afforded by a royal privilege was not granted to just anybody, but only to those inventors who were effectively worthy of merit, and therefore the judgements made could only be entrusted to experts: these were originally merchants and craftsmen, who were later replaced, in the second half of the seventeenth century, by the scientists of the Académie des Sciences (Hilaire-Pérez, 2000b: 48-50).

The influence of the Venetian law on the origins of the English patent system is documented by numerous testimonies that date back to the third and fourth decades of the sixteenth century, whilst the first concessions were effectively granted starting from 1552. The interest in the Venetian institution is made quite explicit; for example, in the Discourse of the Commonweal of This Realm of England (1549), ${ }^{4}$ in which it is stated: 'In Venice, as I heard, and in many other places beyond the sea, they reward and cherish every man that brings in any new art or mystery whereby the people might be set to work with such thing as should both find their workmen and also bring some treasure or other commodity into the country' (Dewar, 1969: 88). An interest underlined also in a following passage: 'I have heard say in Venice, the most flourishing city at these days in all Europe, if they may hear of any cunning craftsman in any faculty, they will find the means to allure him to dwell in their city; for it is a wonder to see what deal of money one good occupier does bring into a town though he himself do not gain to his own commodity but a poor living' (Dewar, 1969: 124).

In England too, as in France, in the second half of the sixteenth century, the introduction of an institution for the recognition of the rights of inventors was aimed at reaching a fundamental objective of mercantilist policy: to encourage foreign technicians and craftsmen to emigrate beyond the Channel and start up new manufacture and so render the kingdom less dependant on importation.

4 Text attributed to Sir Thomas Smith (Dewar, 1969). 
The criteria of evaluation adopted by the English government for the granting of patents were of an essentially political and economic nature: they considered worthy of acceptance those applications in which an 'import substitute', either product or process, was presented; it had to be less costly than the corresponding imported goods and not to conflict with the interests of local craftsmen. Once the patent was granted, the patentee was expected to start up his invention and to transmit his knowledge to the workers employed (MacLeod, 2002: $10-13)$.

At the beginning of the seventeenth century, both the partial disillusion with the results obtained through the mercantilist strategy and, above all, the prevalently clientelist use that the crown had made of patents, brought about widespread discontent and an increasing hostility towards every form of monopoly. The battle against monopolistic privilege led to the approval of the Statute of Monopolies in 1624, which regulated the question, limiting abuses in the concession of patents. In reality the state did not introduce radical innovations relative to patents for invention, except for limiting the period of the monopoly to 14 years, but the measures had the important function of transforming what had been simply a practice under the Elizabethans into an institution. Thus, what would remain the distinctive characteristic of the system until the middle of the following century was consolidated; the state gave up on scrutiny of the technical content of the applications for patents (MacLeod, 2002: 14-19).

The institution that safeguarded the property rights of the inventors in the Dutch Republic was established towards the end of the sixteenth century and had particular characteristics. The first of these was without any doubt the multiple character of the organisms that had the faculty of granting patents for invention: the States General, the Estates of the provinces, and the city councils. Between the end of the sixteenth century and the 1640s it was the States General in the Hague which granted the largest number of patents, while from the middle of the century onwards this primacy passed to the States of Holland, the most dynamic among the provinces of the Republic, but it does not seem that - on the contrary to what happened in France and England - the choices of these two institutions were guided exclusively by mercantilist aims. Initially the duration of the patent could vary from five to 12 years, but around the middle of the seventeenth century this settled down to around 15 years. Another particular aspect of the Dutch institution was given by the fact that the granting of the patent was subordinated both to a procedure of very strict evaluation, at least in the beginning, and to the obligation of implementing the invention within the year. The applicants were in fact expected to furnish a description, a drawing or a model of the invention by which it was judged by a Commission of the States General, which could consult external experts. Such a procedure seems to have fallen progressively out of use from 1635 onwards, leaving it up to the clause regarding the obligatory setting up of the invention to determine the success or failure of the invention (Davids, 2000: 263-268). 
By the end of the sixteenth century, all of the Western European states had instituted forms of safeguarding the rights of intellectual property, inspired by the Venetian law of 1474. It goes without saying that it was not yet a recognition of intellectual property in the terms we consider it today, but more the concession of a privilege for a presumed invention, to which the state attributed some public utility. This institution was adopted in political contexts which were very different one from the other, but, in the first phase of application, it was introduced above all with the purpose of encouraging the immigration of specialized craftsmen from outside, as had happened in Venice and in France and England too, although the Spanish context was less clear and the Dutch system differed from the others - there, however, the system was established at a later date. In all the states considered, we find the essential elements established by the Venetian institution: the form of the privilege, the prolonged monopoly over a varying number of years, the more or less cogent necessity to make the invention operative, the guarantee against plagiarism and the possibility of negotiating the patent and of conceding licences to others.

That which distinguished the different national experiences into two distinct basic types was the importance attributed to the preliminary examination. The judgement of applications for privileges was in general two-pronged. On the one hand, they considered the political-economic impact that the invention might have on the existing framework in terms of possible conflict with the guilds, of any detriment to the existing manufacture, of an increase in prices, and so on. On the other hand, the technical content of the proposed invention was evaluated, often judged through the description, a drawing, or a model. The first type of examination - that of a political-economic nature - was present in all the national systems, and though varying in severity through time, was always in vigour. The technical evaluation - and the forms of the presentation of the invention connected to it - was not prescribed by the English, and where it existed elsewhere, fell progressively into disuse, with the single exception of France. Thus, there were two diverse models that remained such until there was a partial convergence in the second half of the eighteenth century. On the one hand there were states which acted upon the costly - in terms of organization - procedure of effective preliminary analysis of the technical worth of the applications, leaving judgement up to the market, and on the other, the French state, which instead involved the bureaucratic apparatus and the scientific institutions in evaluating and eventually declaring the validity of the invention for which the privilege had been applied for.

Behind the construction of the two diverse institutional structures were the divergent policies adopted in France and in England. In France the scientific community, represented by the Académie des sciences, had a public function, that of supplying the monarchy with the tools and knowledge necessary to the act of governing. Science was in the service of the state and the Crown was the patron of scientists. It is not therefore surprising that, in this system of 
reciprocal legitimation, the Académie des sciences was entrusted with the task of examining the projects submitted by those desirous of obtaining the privilège (Hilaire-Pérez, 2000b: 48-50). In England, the attitude of the political powers, especially after 1660 , was completely different. The procedure for the granting of patents was transformed into a simple act of registration: the state did not make any commitment to guaranteeing or to legitimizing the patentees projects in society. The government and the monarchy used the patents for a variety of aims, amongst which the promotion of the innovation was not however a primary goal: ${ }^{5}$ Elizabethan industrial policy was by that time only a memory (MacLeod, 2002: 20-39, 201-202; Hilaire-Pérez, 2000b: 42-47). Underlying this divergence, we might also find the contrast between two distinct philosophies regarding intellectual property rights: the severe formal procedure of preventative evaluation in use in France was part of a framework of positive law, while the apparent pragmatism of the English system seems to make reference rather to a vision inspired by 'natural law' (Hilaire-Pérez, 2000b: 315). In the end, however, I believe that it was the particular nature of the bond between science and political power that made the French situation unique in respect of the other European experiences.

\section{The management of the privilege}

The European diffusion of the privilege for invention had some important consequences for the economic life of the continental states. As we have already seen, the policy of privileges was employed as a strategic weapon in the mercantilist conflict that developed between the sixteenth and the seventeenth centuries. Thus a further ingredient, the struggle for the control of technical know-how, was added to the competition between states, which, according to some economic historians, was to contribute to European economic growth in a decisive manner (Jones, 1981; Rosenberg and Birdzell, 1986). ${ }^{6}$ It was a competition for technical primacy which involved even the minor states, such as the tiny republic of Lucca, which, from 1554, had a special 'office'- Offizio sopra le Nuove Arti - with the task of 'examining the ways of introducing new "arts" to the city, by searching for and finding men who were expert and able in these' (Sabbatini, 1996: 21). Technical knowledge was essentially practical, based on know-how jealously guarded by the single craftsman: as a consequence, the diffusion of such knowledge depended first and foremost on the migration of those in possession of that self-same know-how, rather than on the proliferation of technical treatises (Cipolla, 1972: 46-52; Landes, 1998: 278).

In the sixteenth and seventeenth centuries, the privilege therefore had a decisive role more in the diffusion of technical know-how, than in the promoting of

5 Apart from, to some extent, naval and military matters (MacLeod, 2002: 35-39).

6 This point of view is discussed by Mokyr (2002: chapter VI). 
invention (Long, 2000: 231), offering a vast range of opportunities for the mobility of technicians and craftsmen, who had, in their turn, to develop skills for the handling of this new opportunity. Those who aspired to obtain a privilege for invention learnt how to use more than one institutional channel, and to play the card of applying to more than one patron: central governments and city councils in Italy, States General, and States of the provinces in the Dutch Republic, monarchy, and parliament in France. These strategies allowed them to lay off the risk that the privilege might not be granted and extended tutelage of the invention over more than a single territory. For example, between 1671 and 1678, the Dutch technician Jan van der Heyden obtained patents for firefighting equipment from the States General, the States of Holland, and the States of Friesland (Davids, 2000: 276-277). In particular, in the Italian peninsula the presence of numerous states of reduced dimensions offered technicians and craftsmen the chance of applying for the same privilege in more than one state at the same time, with the aim of reducing the risks of plagiarism from false claimants who intended to acquire the patent in a neighbouring state (Belfanti, 1996: 136-138; Molà, 2000: 204). From this perspective, it is interesting to see the example offered by Giovanni Battista Guidoboni, who, in the second half of the sixteenth century, obtained from the Republic of Venice a privilege which safeguarded a vast range of inventions - from the breeding of silkworms to the heating of houses to the conservation of cereals. In 1586, he set up a company with a Jewish businessman - who held a $25 \%$ share of the partnership with the aim of obtaining privileges for all his inventions in all of the Italian states as well as in the kingdoms of France and Spain (Molà, 2000: 204-214).

The example quoted illustrates how, besides acquiring the skills needed to deal with the administrative aspects, the privilege holders were also induced to develop strategies that allowed them to exploit the monopoly obtained from the state for commercial ends. ${ }^{7}$ One of the basic necessities was that of finding a partner to finance the effective putting into practice of the invention in exchange for a share in the profits. In the Dutch Republic, financial support to inventors took different forms: the creation of a company with one or more partners, some of who also financed similar schemes; using the resources offered by the family network; and financing on the part of public institutions (Davids, 2000: 273278). England was the country in which the patentees exploited the commercial potential of the patent to the maximum and in the most unscrupulous manner: so unscrupulous that Christine MacLeod has elaborated the distinction between 'heterodox' and 'orthodox' uses for patents (MacLeod, 2002: 78-93). In the second half of the seventeenth century, the first prevailed, in that the interests of political power still seriously conditioned the granting of patents (MacLeod,

7 See examples in Berveglieri (1995: 29); Davids (2000: 267 and 2003: 14-15); Heller (2000: 256); Hilaire-Pérez (1991: 914); MacLeod (2002: 89-93). 
2002: 34-39). In that age in fact the patents were not used solely as a means of safeguarding an invention, but had a much wider use as a tool for cutting out or delimiting market areas to the advantage of manufactures or commercial activity that wanted to free itself from the ties imposed by the guilds or to construct some kind of brand identity for a product (MacLeod, 2002: 39, 81-88).

The introduction of the privilege for invention and its diffusion across Europe in an approximately similar fashion defined an institutional framework that recognized intellectual property and allowed the holders to cede shares and to concede licences or franchises: this framework, consolidated and legitimated, favoured the inception between the sixteenth and the seventeenth centuries of what we may call, with some emphasis, 'a European market for inventions'. Naturally, it was a market still being fully formed, whose establishment was hindered, amongst other things, by the existence of vested interests, such as those of the guilds, who often opposed the granting of patents because they held that they were damaging to their interests and activities. ${ }^{8}$ Nonetheless the process set off by the Venetian law of 1474 was irreversible and, despite the flaws, the abuses and the criticism, in many European countries the privilege for invention continued to be, throughout the eighteenth century too, the fundamental institution for the formal recognition of the rights of inventors, even if the criteria for the granting of patents were significantly reformulated and the procedures were remodelled in that period.

\section{From mercantilism to market}

It was precisely the unscrupulous use of the commercial opportunities offered by the privilege for invention that dragged the institution into a grave crisis of credibility, when, at the turn of the century, the French 'privileges' and the English patents were used as tools for participation in the speculation operations leading to bankruptcy which occurred in both countries. In the decades that preceded and followed the beginning of the eighteenth century, the privilege attracted many more speculators than inventors and was drawn into disgrace along with the adventurers who had used it (Hilaire-Pérez, 2000a: 287-288). Nonetheless, the crisis that followed the bursting of the speculation bubbles induced the British and French governments to apply a more severe privilege policy, which rehabilitated the institution, binding it in a much clearer fashion to the aim of safeguarding invention.

In England, there were two changes in the regulations, adopted in the first half of the eighteenth century, which made the patent a more appropriate instrument of protection for the inventors. On the one hand, limiting to a maximum number of five the people who could hold a patent: this limit on

8 See case-studies in Belfanti (2004: 576-580); Hilaire-Pérez (1991: 916 and 2000b: 48); MacLeod (2002: 82-84, 112-113); Mokyr (2002). 
the total of shares in patents was introduced in 1720 as part of the measures to stem the damage consequent to the so-called 'South Sea Bubble'. On the other hand, the obligation to furnish a detailed written description of the invention that was proposed for the patent. Producing specification that illustrated the object of the patent was already in use, albeit sporadically, from the first decade of the eighteenth century, but it became the norm from 1734 on. The level of detail to which the specification had to be drawn up had not however been established and therefore depended on the applicant's own choice: for example, inventions relative to mechanical devices were often carefully described and, at times, accompanied by a sketch, although other petitioners were frequently reluctant to supply detailed descriptions before the granting of the patent. Nonetheless adopting a formal procedure of specification of the object of the application finally freed the system from favouritism and patronage as well as the abuses of speculation that had marked the preceding decades (MacLeod, 2002: 40-57).

Giving validity to an invention was not in any way an assumption of responsibility on the part of the state: the test of its efficacy was always left up to the market and eventually to the common law courts, charged with the examination of litigation relative to patents after 1750 . This was a peculiarity of the English system: in effect, given the state's lack of commitment to the process of selection and legitimization of the patents, it was often the law courts that played a decisive role, since the effective economic value of the inventions patented depended also on the ability of the patentee to defend his rights against plagiarism. ${ }^{9}$ Bringing an action to prosecute infringements meant however involving oneself in a long and costly process, whose outcome was uncertain, since the legal framework was quite unclear and the courts' competence on technical questions was limited. The actors were well aware of the situation, as is testified to by Jedediah Strutt of Derby, an important inventor active in the sector dealing with textile technology, who in 1758 wrote thus to his partner regarding one of his inventions: 'We may readily have the patent for money enough but then he is sensibile we shall have innumerable enemies that will endeavour to disturb us and afraid we shall nor be able to contend with'em.' 10 Nonetheless, it was precisely from the work of the law courts that solutions destined to safeguard the interests of the inventor in a more effective manner were to emerge: the process leading to a more attentive consideration of the needs and rights of the patentees made important progress with two decisions made by the chief justice Lord Mansfield in 1776 and 1778. The first ruled that an improvement made to an already existing invention could be safeguarded by patent; with the second it was established that the description of the innovation

9 'Indeed, by the late eighteenth century, it was becoming a dictum that a patent was of little commercial value until it had been successfully defended in the court' (MacLeod, 2002: 73).

10 Quoted by MacLeod (2002: 61). 
patented had to be precise and detailed to such an extent as to allow any expert in the sector to understand how it worked: if this, on the one hand, could expose the inventor to the risk of piracy, on the other, it made specification a strong point for the patent in case of prosecution for infringement. However, despite this progress, going through the law courts was a way of enforcement that did not cease to be full of pitfalls for the patentee (MacLeod, 2002: 49, 58-74).

Nonetheless, the introduction of more severe requirements could not but favour the 'real' inventors, discouraging those who were only interested in the exclusively commercial exploitation of the patent. Moreover, the procedural changes led to an ever-greater focalizing on the innovative activity and discouraged those applicants who presented grandiose but totally unrealistic projects. The partial renewal of the institution probably contributed to increasing its trustworthiness as a form of safeguard for invention. From the 1730s patents ceased to be a means employed with the aim of acquiring know-how from abroad and became increasingly the way to safeguard English inventors involved in sustaining the technical progress of the national industry (MacLeod, 2002: 4057). In the second half of the century, then, recourse to the patent was further stimulated by the reduction of costs - real, administrative and commercial besides, of course, by the transformations taking place in the English economy (MacLeod, 2002: 145-157).

In France, too, the first decades of the eighteenth century saw increasing intolerance towards privileges and this attitude combined with a reinforcing of the already present idea that invention was a public good and the inventor at the service of the state. The process of revision of the mechanism of the privilège began by reinforcing French originality, or rather that of the central role of the preliminary evaluation, in which the scientific approval of the Académie des sciences continued to play a decisive role, but which also involved representatives of the bureaucracy. From 1722, the administrative body charged with examining the applications was the Bureau de commerce, whose action renewed the Colbertist tradition, placing promotion of innovation firmly in the centre of the strategies aimed at stimulating economic growth. However, the discredit into which the privilège had fallen in the preceding decades and the emerging conception of an invention as a public good led to public intervention operating principally through the giving of prizes, tax exemptions, honours, and titles, or of simple privilèges, limiting the granting of privilèges exclusifs. This trend produced further stiffening in the policy of patents culminating in the measure taken in 1762, through which the privilège exclusif was a recognition that was reserved for only those inventors whose contribution to the progress of the country had been ascertained by a panel of experts. Moreover, the maximum duration of a privilege was fixed at 15 years with the obligation of the disclosure and the implementation of the invention within the year (Hilaire-Pérez, 1991: 922-925 and 2000b: 314-318). 
The French privilege policy was subject to a new shift from 1776. The changeover at the helm of the government, the will to sustain the economic trend, and the attention to what was happening in England are all possible factors that explain the return to a wide use of the privilège exclusif, which brought the French institution closer to the English one. Underlying the change there was a different view of those for whom public intervention was intended: from Necker on they were identified with the entrepreneurs, considered - in an ante litteram Schumpeterian view - as the actors of economic development and therefore the ideal partners for the policy of innovation. This evolution had direct repercussions on the strategies adopted by the inventors: in the second half of the 18 th, the number of individual inventors who applied for the privilege exclusif diminished, while the number of those who had set up companies with the support of financing partners increased. As an example, it is not by chance that we find companies that knew how to best exploit the advantages offered by the new privilege policy, at the origins of the new chemical industry, a sector with high capital intensity. The alignment of the privilège with the patent took place, on the one hand, through the simplification of the procedure for the preliminary examination, and, on the other, through allowing the market to judge the efficacy of the invention. In fact, the practice of presenting a description of the invention that had been granted the privilège began to spread, substituting the scrupulous preliminary examination, typical of the French institutional tradition. This was an important change of direction, which brought the privilège notably closer to the patent. Amongst the principal supporters of the new trend was Jean-François de Tolozan, head of the Bureau de commerce between 1787 and 1791, in whose opinion adapting the French system to the English model would help to fill the technological gap that was being created between the two countries, as he himself wrote in 1789: 'Je fonde mon avis sur l'expérience constante des anglais, qui n'ont acquis sur nous dans les arts une si grande supériorité qu'en accordant des privilègese à tous ceux qui en demandent, pourvu que ce qu'ils proposent d'exécuter soir fait d'après des principes différents des ceux connus et mis en pratique par d'autres artistes'11 (Hilaire-Pérez, 2000a: 248-259, 297-299, and 2000b: 322-325).

So from starting points that were almost opposite, the evolution of the privilege for invention in France and England converged over the course of the eighteenth century towards the definition of an institutional form that was better able to respond to the needs of the inventors and also possibly more deliberately aimed at stimulating inventive activity on the part of the native-born, rather than at attracting skills from abroad. In the meantime a common tendency towards almost standardizing the preliminary evaluation was being established, making it an administrative procedure - with the adjustments of opposite character that we have seen in France and in England - in order to leave it up to the market 
forces to determine the success or failure of an invention. A significant divergence between the two systems nonetheless remained: the costs of obtaining a patent were decidedly different from those of getting a privilège. The procedure for the granting of the patent cost around $£ 100$, while the French inventor who aspired to a privilège had to undertake the cost of the investment necessary for the making and presentation of his innovation to the administrative bodies who had the task of evaluating it, but might then have obtained money prizes or financial backing for the starting up of a business (MacLeod, 1991: 891).

The reform of the institution, which gave it new legitimacy, combined with the process of transformation of the European economy which had been set off in the second half of the eighteenth century, stimulated the recourse to privileges for invention, the granting of which increased considerably in the last decades of the century both in France and in England (Hilaire-Pérez, 2000a: 297-299 and 2000b: 322-325). The 'rehabilitation' of the privilege was extended as well to other countries in which institutional changes had been made: for example, a similar quantity tally has been found for the Venetian Republic where reforms of the patent regulations were not adopted, probably because the economic stagnation had not permitted speculation initiatives (Berveglieri, 1995: 22).

In Spain, too the second half of the eighteenth century was a period of 'rebirth' for the patent. The lack of studies on the question does not allow us to reconstruct the quantitative dimensions of the use of the Cédulas de privilegio between 1630 and 1750: the little information available, however, seems to suggest an extremely limited number of concessions. What is known for certain is that there were no significant changes in the procedure. Only after 1759, with the accession of the reforming king Carlos III and the start of a phase of strong state support for technical progress, is the Cédula de privilegio resumed as a tool for promoting economic development. The number of patents granted increases above all from 1770 on. However, for reasons that are difficult to ascertain - most probably due to scarce familiarity with the institution - the would-be inventors found the privilegio only a partially satisfactory solution for the safeguarding of their interests, and had wide recourse to money prizes and other forms of incentive proposed by bodies such as the Sociedades Economicas de Amigos del Pais (Sàiz Gonzàlez, 1999: 78-81, 106-109).

The situation in the Dutch Republic ran definitely counter to the trend. There, from the end of the seventeenth century, the number of patents went steadily into decline. According to Karel Davids, the explanation for the decline of the institution does not lie in the stagnation of the economy, nor in the further stiffening of the corporative nature of society, nor even in the drying up of inventive activity, but rather in the emergence of a private institution, the 'Oeconomische Tak van de Hollandsche Maatschappij der Wetenschappen', created in 1777 in imitation of the English Society of Arts ${ }^{12}$ with the aim of 
promoting economic progress through the spreading of know-how; ${ }^{13}$ in his view inventors preferred the prizes and recognition handed out by this institution to the granting of a patent (Davids, 2000: 278-280).

The Dutch and the Spanish examples introduce an institution that appeared on the European scene in the course of the seventeenth century and offered itself as a source of protection for inventors. These institutions were private Societies whose members were scientists, technicians, and gentlemen; they arose in almost all the European states with the objective of promoting economic and social growth through the diffusion of knowledge ${ }^{14}$ and probably represented one of the cardinal points on the long journey towards 'the institutionalization of open science' (David, 2003). These Societies stimulated inventive activity by distributing prizes for inventions worthy of note, but, above all, by conceding to merit-worthy inventors the recognition of an institution whose legitimacy derived directly from the scientific prestige of its members. In other words, the Societies offered the inventors the chance to obtain a public avowal of scientifictechnical validity - at times accompanied by a money prize - which in some cases could constitute an effective alternative to the privilege ${ }^{15}$ - as happened in the Dutch case and, to some extent, in the Spanish one.

\section{To sum up}

The origins of the modern intellectual property institutions can be traced back to the Late Middle Ages, where measures for recognizing and rewarding craftsmen's skills were conceived and put into practice: such widespread 'social technologies' (Nelson and Sampat, 2001) were institutionalized under the 1474 Venetian law, which was then imitated in the other European states. The objective of the law was that of acquiring technical know-how, by making immigration attractive to craftsmen through the concession of franchises and monopolies. The juridical tool used to reach this aim was the privilege, already a tried and tested instrument taken from the institutional 'kit' that the governments of the time had at their disposal. In other words, the measures adopted by the European states between the fifteenth and the sixteenth centuries did not aim at creating a form of explicit safeguard for intellectual property, or at promoting the activity of invention, but were solely intended to reach a concrete economic policy objective by using the institutional mechanism of the privilege. This was all that the cognitive frame of the rulers and the organizational structure of the states could produce at that epoch. Nonetheless, the spreading of the privilege for invention had decisive consequences for the evolution of the intellectual

13 See also Mokyr (2005: 315).

14 See Mokyr (2005: 312-317, 332-336).

15 See Hilaire-Pérez (2000a: 294-297 and 2000b:189-220, 320-322); MacLeod (2002: 182-200); Sàiz Gonzàlez (1999: 78). 
property institutions. In the first place, the principle that craft knowledge was a legitimate form of intangible property was established. Secondly, the adoption of the Venetian system as a reference model led to the institutionalization of the privilege in forms that were in a large measure common to the majority of European states. The spreading of the privilege in fact laid the institutional basis for the formation of a European market for invention. To agree with Nelson and Sampat, 'Developing an institutionalized way of doing something may be the only way to achieve a low transaction cost way of doing it' (Nelson and Sampat, 2001: 47). Thirdly, we must remember that the privilege, though originally an instrument for parcelling out all sorts of benefits and franchises, was more than once remodelled in order to transform it into an institution destined principally to respond to the safeguarding of the rights of inventors. However, the concrete efficacy of the privilege in terms of satisfying the needs of the inventors must always be judged in relation to the existence of alternative channels for the exploitation, under formal models, of the advantages deriving from an invention. The confrontation was played out on the comparison of the costs and the opportunities that the various solutions at their disposal would involve (Hilaire-Pérez, 2000b; MacLeod, 1991 and 2002). As we have seen, in the eighteenth century, the competition had become fiercer, but, at least judging by some quantitative evidence, that of the privilege continued to be the solution preferred by the inventors in the Republic of Venice, in France, in England.

\section{References}

Belfanti, Carlo Marco (1996), 'Fashion and Innovation: the Origins of the Italian Hosiery Industry in the Sixteenth and Seventeenth Centuries', Textile History, 27: 132-147.

Belfanti, Carlo Marco (2004), 'Guilds, Patents and the Circulation of Technical Knowledge: Northern Italy during the Early Modern Age', Technology and Culture, 45: 569589.

Berveglieri, Roberto (1995), Inventori stranieri a Venezia (1474-1788), Venezia: Istituto veneto di Scienze, Lettere e Arti.

Botero, Giovanni (1948), Della ragion di stato ... con tre libri delle cause della grandezza delle città, L. Firpo (ed.), Turin: UTET.

Braunstein, Philippe (2003), Travail et entreprise au Moyen Age, Bruxelles: De Boeck.

Brown, Lawrence A. (1981), Innovation Diffusion: A New Perspective, London: Methuen.

Cipolla, Carlo M. (1972), 'The Diffusion of Innovations in Early Modern Europe', Comparative studies in Society and History, 14: 46-52.

David, Paul A. (1993), 'Intellectual Property Institutions and the Panda's Thumb: Patents, Copyrights, and Trade Secrets in Economic Theory and History', in M. B. Wallerstein et al., The Global Dimensions of Intellectual Property Rights in Science and Technology, Washington, DC: NAS, pp. 19-62.

David, Paul A. (2003), 'From Keeping “Natutre's Secrets” to the Institutionalization of "Open Science", SIEPR Papers, Stanford. 
David, Paul A. (2004), 'The End of Copyright History', paper presented to the 4th Conference European Policy and Intellectual Property, Paris, 1-2 October 2004.

Davids, Karel (2000), 'Patents and Patentees in the Dutch Republic between c. 1580 and 1720', History and Technology, 16: 263-283.

Davids, Karel (2003), 'Guilds, Guildsmen and Technological Innovation in Early Modern Europe: the Case of the Dutch Republic', Working Paper of the Project 'Economy and Society of the Low Countries in Pre-industrial Period'

Dewar Mary (ed.) (1969), A Discourse of the Commonweal of This Realm of England Attributed to Sir Thomas Smith, Charlottesville: The University of Virginia Press.

Garcia Tapia, Nicolàs (1990), Patentes de invenciòn espanolas en el Siglo de Oro, Madrid: OEPM.

Garcìa Tapia, Nicolàs (1998), 'The Origins of Invention Patents in Spain', paper presented to the 12th International Economic History Congress, Madrid.

Heller, Henry (2000), 'Primitive Accumulation and Technical Innovation in the French Wars of Religion', History and Technology, 16: 243-262.

Hilaire-Pérez, Liliane (1991), 'Invention and State in 18th-Century France', Technology and Culture, 32: 911-931.

Hilaire-Pérez, Liliane (2000a), 'Technical Invention and Institutional Credit in France and Britain in the 18th-Century', History and Technology, 16: 285-306.

Hilaire-Pérez, Liliane (2000b), L'invention au siècle des lumières, Paris: Albin Michel.

Jones, Eric L. (1981), The European Miracle, Cambridge: Cambridge University Press.

Landes, David (1998), The Wealth and Poverty of Nations, London: Little, Brown \& Company.

Long, Pamela O. (1991), 'Invention, Authorship, "Intellectual Property", and the Origin of Patents: Notes toward a Conceptual History', Technology and Culture, 32: 846-884.

Long, Pamela O. (2000), 'Invention, Secrecy and Theft: Meaning and Context in the Study of Late Medieval Technical Transmission', History and Technology, 16: 223-241.

Long, Pamela O. (2001), Openness, Secrecy, Authorship: Technical Arts and the Culture of Knowledge from Antiquity to the Renaissance, Baltimore and London: The Johns Hopkins University Press.

MacLeod, Christine (1991), 'The paradoxes of Patenting: Invention and Its Diffusion in 18th and 19th Century Britain, France and North America', Technology and Culture, 32: 885-910.

MacLeod, Christine (2002 [1988]), Inventing the Industrial Revolution: The English Patent System 1660-1800, Cambridge: Cambridge University Press.

Mandich, Giulio (1936), 'Le privative industriali veneziane (1450-1550)', Rivista del diritto commerciale e del diritto generale delle obbligazioni, 24: 511-547.

Mandich, Giulio (1958), 'Primi riconoscimenti veneziani di un diritto di privativa agli inventori', Rivista di diritto industriale, 7: 101-155.

Mokyr, Joel (2002), The Gifts of Athena. Historical Origins of the Knowledge Economy, Princeton, NJ: Princeton University Press.

Mokyr, Joel (2003), 'Mercantilism, the Enlightement, and the Industrial Revolution', paper presented to the Conference in Honor of Eli F. Heckscher, Stockholm, May 2003.

Mokyr, Joel (2005), 'The Intellectual Origins of Modern Economic Growth', The Journal of Economic History, 65: 285-351.

Molà, Luca (2000), The Silk Industry of Renaissance Venice, London and Baltimore, London and Baltimore: The Johns Hopkins University Press. 
Nelson, Richard R. and Bhaven N. Sampat (2001), 'Making Sense of Institutions as a Factor Shaping Economic Performance', The Journal of Economic Behavior and Organization, 44: 31-54.

Rosenberg, Nathan and Luther E. Birdzell (1986), How the West Grew Rich, New York: Basic Books.

Sabbatini, Renzo (1996), L'invenzione prudente, Firenze: Le Lettere.

Sàiz Gonzàlez, Patricio J. (1999), Invenciòn, Patentes e Innovaciòn en la Espana Contemporanea, Madrid: OEPM.

Strang, David and John W. Meyer (1993), 'Institutional Conditions for Diffusion', Theory and Society, 22: 487-511. 